\title{
Formation of foreign language competence of future metallurgies by use of information and communicative technologies
}

\author{
I. Zaichenko \\ Dniprovsk State Technical Univers Ukraine \\ Corresponding author. E-mail: Irinayarema@gmail.com
}

Paper received 12.06.19; Accepted for publication 01.07.19.

\section{https://doi.org/10.31174/SEND-PP2019-201VII81-11}

\begin{abstract}
Annotation. The article deals with process of formation of foreign language competence of future metallurgies by use of information and communicative technologies. Analyzed problems of use ICTs in learning process, methods of teacher and student interaction. Studied requirements for introduction ICTS into the learning process and described stages of creation multimedia complex for metallurgy specialties students. Described some specific disadvantages of ICTs in use.

Keywords: foreign language, competence, student, information and communication technologies; communicative competence, metallurgists; multimedia.
\end{abstract}

Introduction. Recently information and communication technologies were used only in the exact sciences, but now they are becoming popular in foreign language teaching as well. ICTSs help to solve the following problems: 1) provide access to the Internet to every participant of the educational process at any time and from any location; 2) create a single information space of learning industry and help to take part in the educational process; 3 ) promote the development and effective use of managed information and educational resources. Informatization processes in foreign language teaching mustn't be understood as the formation of only technical means of teaching, they must increase the effectiveness of learning, make it easier and interesting for students. Educational environment that involves ICTSs is based on such interactive components: 1) technical (use of computer and means of communication); 2) software and hardware (means of support of the teaching method); and 3) methodical (instructions to students and teachers, organizing of the whole learning process).

The aim of educational system is development of creative personality ready to work effectively. The model of competence of the individual includes the following components: 1) social competence, which is based on the learning of the main social practices and rules; 2) intellectual and communicative competences, the ability to use modern methods and technologies of communication; 3) awareness of your own social and cultural identity in historical and cultural environment; 4) ideological competence, which presupposes respect for the values and norms of other cultures; 5) professional competence [8].

Modern labor market poses new challenges of higher education under the influence of globalization processes. Future specialists must have a special type of thinking which corresponds to the requirements of the information society. Information and communication technologies are increasingly used in various areas of educational activity, making influence on the educational system and the society's everyday life. Information and communication technologies is a term that includes a variety of methods, techniques, algorithms of data collecting, storage, presentation processing and transmission of information.

Analysis of the problems of using ICTSs in the educational process. Analysis of the problems of using ICTS in the educational process shows that the transition to computer-based means of teaching, creating conditions for their development and implementation, rational combination of innovational methods with traditional is a complicated task, which requires solving a complex of psycho-pedagogical, organizational, teaching and logistical issues. And one of the main of them is the development of appropriate teaching methods for use information retrieval systems: multimedia, hypermedia, telecommunications and network technologies.

The researchers studied a number of pedagogical conditions of optimization foreign language teaching process by the means of ICTSs. Among them, says R. Yagelski, is the content provided conditions "characterized by rational, scientific and reasonable selection of educational information, its structuring, development, implementation and updating of learning courses" [9]. Forms and means of learning foreign language optimal to course content must be selected.

The problem of information and communication technologies remains relevant in recent years and is studied by A. Blunden [1], D. Davidson [2], J. Leakey [4], P. Sysoyev [5], I. Robert [7] and others. In these studies authors share their experience, discuss the advantages and possible disadvantages of using ICTSs. Interactivity of information technologies provides hypertext and multimedia, suggests transition into a new level of work with the information. The potential of ICTS is truly boundless. They develop abilities of differentiated approach, help to improve the visualization training and organize the independent work of students, ways of teaching control, provide the students with teaching materials. These technologies allow the development of common network thinking, change outlook on life and relationships between people.

Didactic opportunities of ICTSs are studied and described in details. General didactic teaching methods include the use of information and communication technologies. Let's show the most suitable methods of teachers and students interaction:

Method of transferring new knowledge. Digital educational resources are based on this model, they facilitate mass access to educational materials from any place and time. The disadvantage of this method is that the student is a passive recipient of information.

The method of processing and consolidation of skills and abilities. In this method information and communication technologies allows you to create a base of teaching resources, use feedback regularly, which increases the 
degree of assimilation of the required material. If to use the method of processing and consolidation of skills and abilities regularly, the potential of ICTSs is fully revealed and teachers role in the process of studying is changed. The limitations of this method may consist of a lack of information competence of the teacher;

The method of production of new knowledge based on the experience of application of information and communication technologies in the methods mentioned above. In this method students must build their own strategy for dealing with educational problems, evaluate information critically and analyze different approaches to solving problems. The role of the teacher is to support the educational process. This method increases teacher's responsibility for the process of understanding teaching material by the students, involves high motivation, critical thinking, effective interaction between students and teacher. Such motivation factors as the ability to lifelong learning, responsibility and commitment are important tools for acquiring knowledge. Disadvantages of this method are high requirements for information and communications culture of teachers.

The priority of foreign language teaching in higher education is forming of communicative competences of students for solving professional tasks. Using ICTs in foreign language leaning has the following advantages:

- interactivity of learning materials promote interest in foreign language studying;

- ability to adapt the educational process to the needs of each student.

- convenience of work with such materials at any time and from any place.

An integral part of the educational process is the use of the World Wide Web to communicate with native language speakers, sharing information, movies and films in foreign languages. ICTs provides high informative capacity of the material, increase the motivation of students and stimulate their cognitive activity, allow to solve many didactic problems:

- forming skills and abilities of all kinds of speech activity;

- enrichment of active and passive vocabulary of students;

- formation of social, cultural and geographic competence of srudents;

- imitation of the language environment.

As an authentic online resource you can use Lingua Leo, Learn English Elementary, Wordshake, Learning English With The New York Times, etc.; online educational resources for teachers of foreign languages: Air Force learning / teaching Websites; dictionaries on electronic media - ABBYY Lingvo; Online dictionaries: Lingvo, Webster, Multiflex, online free dictionary, Multitran, and others. The biggest video hosting is considered YouTube, this service can contribute to the development of listening skills, monologue and dialogue speech.

You can work with audio files in such a way: Introduction (Instructions) - first audition - definition of the basic meaning - work with the key words - checking understanding of the content of the audio file - phonetic work with the text - re listening of the audio file. In future, each of the proposed audio file can be used as an effective means of securing a new and repetition of grammatical and lexical material.

However, the use of information and communication technologies in the classroom should not be a main, but the second means of the educational process. Shorting of dialogic communication in real life reduces the possibility of formation critical thinking based on dialogue.

Combined learning (blended learning, or b-learning) can be optimal in the process of foreign language learning. This type of learning means using both classroom lessons and activities with the use of electronic means. The advantages of both types of learning are combined in this method. Blended learning allows the teacher to speak in a new role and maintain the full-time communication in a same time.

Requirements for introduction ICTs into the learning process. It is important to rise motivation and interest of the students in the process of studying foreign language. Traditional teaching makes the students passive recipients of knowledge, prevents them from understanding the structure and function of language. The main purpose of foreign language teaching of future metallurgists is getting the ability to use foreign language in professionally oriented speaking. Certainly, the implementation of information and communication technologies in education is an objective necessity of society today. The need to improve the efficiency of the educational process requires an update educational facilities, modernization of teaching methods, maximum orientation for the implementation of educational, informational, communicational needs of today's participants in the educational process.

Information and communication technologies provide knowledge at any time and place and need the development of special competences in the field of education and training. Today is obvious the fact that ICTs must be introduced into the teaching process. But unfortunately, sometimes the use of innovative methods based on ICTs only makes educational process more complicated, leading students to frustrations and failures.

It is easy to avoid such mistakes. We should take into consideration the basic conditions for the successful integration of ICTs in the learning process, namely University must have:

good technical equipment (availability of computers, Internet access);

information educational environment (the unified system of computer hardware, software, training databases, e-learning and teaching resources, virtual learning environments and other elements of implementing information processes);

security of training process;

information and communicative competences of the teacher and students.

Today in the process of learning foreign language various means of information resources are used: research Internet systems, multimedia, telecommunications and network technologies, the boundaries of the educational environment are constantly expanding. The main in building the new information environment must be the principle of psycho-pedagogical usefulness of information technologies. That's why for further optimization and improvements in education must be used multimedia.

We think that visual and bright multimedia software of the training course helps to make foreign language lessons 
interesting and close to real professional situations. Students have an opportunity to discuss various problems connected with a future specialization, can proof their point of view, develop creative and mental abilities and communication skills [3]. Group discussions, individual discussions and debates can also offer more opportunities for communication among students and between teachers and students.

Multimedia means of teaching are series of visual, audio, video and other means of displaying information that are integrated in an interactive software environment. Thus, multimedia technologies in teaching are unique and increase creative thinking of students, their communicational skills in professional practice. So we can say that a special place in the process of foreign language teaching by the means of ICTs is occupied by the multimedia technologies. Multimedia means of presentation educational material belong to a new generation; help to develop visual-figurative thinking; stimulate attention on the stage of presentation material; contribute to enhance teaching and learning activities; form motivation to effective teaching, allow to check your level of knowing foreign language quickly and objectively.

Teacher should fill the educational process with methodological and methodical means, develop training courses. So for high-quality presentation and organization of the process of learning many different technologies are considered. We want to distinguish multimedia technology among them. It allows you to combine the text, graphics, audio and video, animation in one software. An important feature is also the interactivity that allows the user to get feedback. Multimedia can provide harmonious integration of different types of information. By intensifying student's perception of educational material it is possible to involve them in the process of knowledge as learning activities.

The term "multimedia" means interactive systems that provide the processing of video images, animated graphics and high quality sound and speech. Infotmation structures are combined by the hypertext - the technology which works with a text information, set associative links (hyperlinks) between individual terms, fragments, articles and allows free access, associating reviewing according to established connections. Work in hypertext environment can be compared with reading the encyclopedia: encountering unfamiliar term in the text, the reader goes where this term is defined. After reviewing the material, the reader has an opportunity to return quickly to the starting position and continue reading.

The analysis revealed that the benefits and peculiarities of multimedia technologies can be the features that widely used in the studying process:

Increasing the image on the screen, its most interesting fragments. The quality of the image remains the same. This is particularly important for the presentation of technical drawings of mechanisms and schemes; saving a significant amount of diverse information on a single unit.

The modern model of education is difficult to imagine without the use of new information and communication technologies - namely multimedia. The study of the problem of foreign language training of future specialists in metallurgical field confirms the fact that the level of knowledge of students does not meet modern require- ments. The analysis of scientific literature on the problems of the use of ICTs in the foreign language learning has shown that these issues are very relevant to all countries. Analysis of methods and approaches of domestic and foreign authors to intensive foreign language teaching, namely J. Leakey [4], K. Mullamma [6], I. Robert [5] makes it possible to distinguish the following characteristics of foreign language training: classes begin with dialogue, instead of mastering grammar rules; studying a foreign language in a short time due to mobilization personal resources of the individual and its hidden reserves. Students try to communicate in a form of role play. Multimedia approach is effective and based on the use of several complementary information and communication technologies.

Stages of creation a multimedial complex for future metallurgists. The use of ICTS is a fundamentally new approach to the organization of audience and independent work of students, it promotes development of motivational sphere, the desire for independent learning activities. Electronic educational-methodical complex is a modern alternative to traditional means of learning a foreign language. Undoubtedly, electronic means have a number of important didactic advantages over their paper counterparts: 1) multimedia technology helps illustrate bright cognitive and educational information (through the use of text, graphics, audio and video); 2) hypertext technology (through the use of hyperlinks) simplifies navigation and gives students the opportunity to learn the material in an individual basis; 3) various kind of information is saved on one unit. Electronic educational and methodical complex effectively combines the functions of teacher and textbook, reference and information source consultant, means of control of knowledge. First electronic editions were the copies of printed books. Modern media complex allows a wide range of computer capabilities for presentation material. This multimedia (complex hardware and software) gives you an opportunity to work interactively with different data (text, graphics, sound, video) and integrates the them into one unit. Hypertext can obtain additional information which is interesting to the user.

Creation of electronic educational-methodical complex is long and complex process. At the preparatory stage we select texts, illustrations and background materials, create thumbnails of interface and programs and individual blocks (video and animation knowledge tests). Full course aims to use a plain text and hypertext with links on related topics, images, charts, animation, photographs, etc.

The main stage is filling the complex with materials. The content of materials is very important. The form of presentation is better to make strict, pages mustn't contain unnecessary that information that does not distract the user's attention. You must also consider the following requirements and principles: simplicity and ease of use, compliance with curriculum material, openness (manual is an open system that allows you to supplement it with new materials and components, make necessary changes), user-friendly interface (allows you to focus on the learning material of the foreign language).

Here are the examples of electronic educationalmethodical complex "Foreign language for professional purposes" for future metallurgical engineers.

The main objectives of the use of ICTs by teachers of 
foreign languages are: modernization of methods and forms of educational process; optimization of learning content; ensuring of high methodological and scientific level of teaching; improving the efficiency and quality of foreign language training; individualization of the learning process.

Disadvantages of the ICTS use. But sometimes using ICTs has no effect on improving the quality of education, and even has a negative effect. The main reason of it is the lack of media and information literacy of teachers. The educational process requires new kinds of skills from its participants; they must possess new kinds of competence, necessary for life in the information society. To take full advantage of ICTs means to adapt all teaching materials to the new learning environment. ICTs can be able to take advantage of asynchrony, develop mixed teaching models and courses, which take into consideration the individual needs of students.

As practice shows, methodological support for teachers in the field of ICTs can provide network educational community, for example, if you study marketing or economy it can be Google Online Marketing Challenge ( https://www.google.com/onlinechallenge/dmc/); Social Media Quickstarter (http://www.socialquickstarter.com); Alison: Diploma in E-Business (https://alison.com/courses/Diploma-in-E-Business); Online Marketing Articles and Blogs (http://www.entrepreneur.com/marketing/onlinemarketing /); Self Actualization Resource (https://vk.com/undergraduate); Copyblogger Online Marketing Course (http://www.copyblogger.com/imfsp/) and so on.

Also doctors think that use of ICTS is harmful for our health. Statistic says that every user of "3 Dictation" ("3 D" + "Education") has two from five illnesses of the new century. Among them are: carpal tunnels syndrome; problems with eyes; vertebral syndrome, respiratory or pulmonary syndrome and - venous vascular syndrome. become a powerful means of teaching if the teacher will

In spite of the accumulated theoretical and practical experience in the application of information and communication technologies, we can say that the introduction of ICTS in the educational process takes place spontaneously, there is a contradICTSion between the potential and the real possibilities of their use. The effective use of ICTS is possible in such cases:

- the objectives of the educational complex are clearly told and described the ways of their achievement;

methods of use of ICTs in the learning process must be defined;

developed methodical recommendations, containing all necessary information for students and teachers;

special attention is paid to a clear description of the competences formed as a result of learning the course; - $\quad$ faculty and students are prepared and ready to use ICTs;

an information space is created in the university.

Conclusion. We come to the conclusion that introduction modern and innovative communicational technologies significantly alter the possibilities of the teacher, makes lessons more vivid and productive. Multimedial projectors give the opportunity to present material in matrix, which removes the student from the printed text, making the process of learning more interesting and easier. Every multimedia unit is versatile only in a complex application, its didactic abilities and psychological necessity must be justificated during the foreign language teaching. We believe that proper and systematic use of multimedia technology makes it possible to increase the amount of educational material, to achieve a sufficiently high level of foreign language, and to ensure the deepening of professional knowledge.

In summary, we note that the use of ICTs in foreign language training enhances the teacher abilities, awakes students to conscious learning, aims at the formation of the professional and personal qualities, the development of creative learning of students. Thus, the prospect of further research we see in the implementation of information and communication technologies in the process of foreign language professionally-oriented education.

\section{REFERENCES}

[1] Blunden A. (2009) "An Interdisciplinary Concept of Activity”. In: A. Blunden (ed.), Outlines Nr. 1 2009, 1-26. Taylor \& Francis Group.

[2] Davidson D., Lekic M., Soliman M.(2004) Information and Communication Technologies in the Teaching and Learning of Foreign Languages: State-of-the-Art, Needs and Perspectives. Analytical Survey. UNESCO Institute for Information Technologies in Education (IITE), Moscow.

[3] Kaffash H. R. (2010). A close look into role of ICTS in education. International Journal of Instruction, 3(2), 63-82.

[4] Leakey J. (2011). Evaluating Computer Assisted Language Learning: an integrated approach to effectiveness research in CALL, Bern: Peter Lang. http://www.albany.edu/faculty/rpy95/webtext/.

[5] Sysoyev P. (2012). Didactic characteristics and functions of modern information and communication technologies. Foreign Languages at School Journal, 6, 12-21.

[6] Mullamaa K. (2010). "ICTS in Language Learning - Benefits and Methodological Implications". International education studies, Vol 3, No 1. Retrieved August 10, 2012 from http://www.ccsenet.org/journal/index.php/ies/article/viewFile /4965/4131

[7] Robert I. V. (2010). Modern information technologies in education: didactic problems, and use perspectives. Moscow: Russian Academy of Education.

[8] Salehi H., Salehi Z. (2012). "Integration of ICTS in language teaching: Challenges and barriers". 3rd International Conference on e-Education, e-Business, e-Management and eLearning IPEDR vol.27 IACSIT Press, Singapore. Retrieved August 05, 2012 from http://www.ipedr.com/vol27/40IC4E\%202012-F10037.pdf

[9] Yagelski R. (2005). Computers, literacy and being: Teaching with technology for a sustainable future. [8] Keengwe J. (2012) Student and Instructor Satisfaction with E-learning Tools in Online Learning Environment. International Journal of Information and Communication Technology Education $8(1)$. 